\title{
植物种群更新的补充限制
}

\author{
韩大勇 ${ }^{1}$ 张 维 ${ }^{1}$ 努尔买买提・依力亚斯 ${ }^{1}$ 杨允菲 ${ }^{2 *}$ \\ ${ }^{1}$ 伊犁师范大学生物与地理科学学院, 新疆伊宁 $835000 ;{ }^{2}$ 东北师范大学草地科学研究所, 植被生态科学教育部重点实验室, 长春 130024
}

摘 要 补充限制基于生态位理论, 从种子萌发、幼苗存活和生长、繁殖体扩散等生活史阶段的种群统计特征及环境因素(土 壤水分、养分、调落物等)着手, 探讨种群的更新问题。种源限制和微生境限制是补充限制理论研究的核心内容, 但是哪个更 为重要并没有统一的结论。种源限制与种子生产、土壤种子库和地下芽库中的繁殖体数量不足有关。其中, 气候的年际波动、 土壤种子库寿命和动物的捕食都会影响种子生产在种群更新中的作用; 土壤种子库常被视为种群更新的保险库, 与地上种子 雨共同促进种群更新, 但是, 如果土壤里种子具有较高的死亡率和休眠率, 将会降低种子库的作用; 地下芽库及其产生的无 性分株对于种群更新的意义更多地体现在干扰后种群更强的恢复能力上。扩散限制是种群更新中的普遍现象, 与种子产量、 散布能力、传播媒介、幼苗密度等因素有关。微生境限制主要表现为水分、养分、调落物等非生物因素以及竞争、捕食等生 物因素对种子的活力、萌发性、幼苗的存活力、物质分配等过程的影响, 其重要性随着植物生活史阶段而发生变化。未来需 要进行综合的、长期的实验, 并应着重加强种源限制及相关生态过程的进化与生态相结合的机理性研究, 从而更深刻地认识 和理解种群更新问题，建立更为综合、系统的种群更新理论体系。

关键词＼cjkstart种源限制; 微生境限制; 幼苗存活; 地下芽库; 扩散限制

韩大勇, 张维, 努尔买买提・依力亚斯, 杨允菲 (2021). 植物种群更新的补充限制. 植物生态学报, 45, 1-12. DOI: 10.17521/cjpe.2020.0246

\section{Recruitment limitation of plant population regeneration}

HAN Da-Yong ${ }^{1}$, ZHANG Wei ${ }^{1}$, Nuermaimaiti YILIYASI ${ }^{1}$, and YANG Yun-Fei ${ }^{2 *}$

${ }^{1}$ School of Biology and Geography Sciences, Yili Normal University, Yining, Xinjiang 835000, China; and ${ }^{2}$ Ministry of Education Key Laboratory of Vegetation Ecology, Institute of Grassland Science, Northeast Normal University, Changchun 130024, China

\begin{abstract}
Based on niche theory, recruitment limitation is to discuss population regeneration through the population demographic characteristics in different life stages, such as seed germination, seedling survival and growth, propagule dispersal, and varied environmental factors (soil moisture, nutrients, litter, etc.). The core of recruitment limitation consists of seed limitation and microsite limitation; however, there is no universal conclusion on which of them is more dominant. Seed limitation is related to insufficient propagules of seed production, soil seed bank and underground bud bank. Specifically speaking, inter-annual climate fluctuation, soil seed bank life time and animal predation can lead to seed limitation. Soil seed bank is often regarded as the vault of population recruitment, which promotes population recruitment together with the above ground seed rain. In contrast, if soil seeds have high death rate and dormancy rate, the role of seed bank will decline. The contribution of underground bud bank and its clonal ramets for population regeneration are more reflected on stronger resilience to disturbance. Dispersal limitation is a common phenomenon in population regeneration, which is related to many factors including seed production, dispersal ability, spreading media and seedling density. In terms of microsite limitation, embodying in how abiotic factors such as water, nutrients, litters, and biotic factors such as competition and predation effect on seed vigor, germination, seedling viability, and biomass allocation, its importance often varies with the stages of plant life history. In the future, it is necessary to conduct comprehensive and long-term experiments to focus on the underlying mechanisms involving evolution and ecology on seed limitation and its associated ecological processes, so as to obtain a more profound understanding of population recruitment, and establish a more comprehensive and systematic framework of population recruitment.
\end{abstract}

收稿日期Received: 2020-07-23 接受日期Accepted: 2020-11-30

基金项目: 新疆维吾尔自治区自然科学基金(2019D01C332)和国家自然科学基金(31560095)。Supported by the Natural Science Foundation of Xinjiang Uygur Autonomous Region (2019D01C332), and the National Natural Science Foundation of China (31560095).

* 通信作者Corresponding author (yangyf@nenu.edu.cn) 
Key words seed limitation; microsite limitation; seedling survival; belowground bud-bank; dispersal limitation

Han DY, Zhang W, Yiliyasi N, Yang YF (2021). Recruitment limitation of plant population regeneration. Chinese Journal of Plant Ecology, 45, 1-12. DOI: 10.17521/cjpe.2020.0246

植物种群更新问题历来是植物生态学家关注的 焦点(杨允菲等, 2012)。种子从母株上生产、扩散, 再 在适合地点萌发, 进而形成幼株, 补充进入种群, 期间经历来自生物(种内和种间竞争、动物捕食、调 落物等), 非生物(温度、水分、光照等)以及干扰等 多种因子的限制。植物种群更新研究就是围绕种子 的生产、萌发、扩散以及幼苗存活等一系列过程展 开的, 探讨各种因素对植物种群更新过程的相对影 响, 并找出影响种群更新的关键限制因子。

种源限制被描述为种群大小随着种子添加而增 加的现象(Turnbull et al., 2000)。在植物种群更新过 程中, 种源是否充足决定了后续的种子萌发和幼苗 建成过程, 甚至有人认为, 只要种子数量足够多, 就可以摆脱种子萌发、幼苗生长或存活的限制 (Siemann \& Rogers, 2006)。但是, 受可利用资源和 种间竞争的影响, 大多数植物无法产生足够数量的 种子, 由此, 必然产生种源限制问题。McEuen和 Curren (2004)就认为, 北方阔叶林中的所有优势种 在一定空间尺度上都可能存在种源限制。然而, 即 使植物种群摆脱种源限制, 种子萌发和幼苗存活过 程也受到微生境的限制, 如土壤水分、养分、调落 物等。因此, 种源限制和微生境限制是紧密联系的 两个生态过程, 对种群更新以及群落的物种组成和 群落结构具有深远影响。

\section{1 补充限制概念界定}

目前国内学者在进行植物种群更新研究时, 大 多使用更新限制一词。可以简单认为, 影响种群自 然更新过程的任何因素或生态学过程都可以视为更 新限制。但是国外文献中很少有论文使用更新限制 (regeneration limitation), 相反, 使用最多的是 recruitment limitation (本文译为补充限制), 并且外 文文献中对补充限制的涵义也颇有争议。就本身词 义而言, 牛津词典(Oxford English Dictionary online) 对 “recruitment” 的解释为 “The process of finding people to work for a company or become a new member of an organization”, 指的是公司或组织招募 员工的过程, 其主体对象为新成员, 用于生物种群, 则应该是动物幼体、植物种子或幼苗。补充限制一
词最早见于水生生物种群研究, 指的是可用于补充 种群的扩散个体的限制, 发生于扩散阶段之后。但 是补充限制应用于陆地植物研究时涵义比较混乱, 有时候指的是种子限制(McEuen \& Curran, 2004; Mendoza et al., 2009), 有时候指的是幼苗限制 (Barrett \& Silander, 1992; Callaway, 1992)。MullerLandau等(2002)认为补充限制包括种源限制、微生 境限制和种子扩散过程。Münzbergová和 Herben (2005)则认为只有同时包括种子生产和幼苗存活过 程才是补充限制, 而把仅仅由种子数量引起的限制 称为种源限制。

本文限定补充限制包括种源限制、微生境限制 和扩散限制三种类型, 其实质是基于生态位理论, 从种子生产、幼苗存活以及繁殖体扩散等生活史阶 段的种群统计特征及环境因素着手, 探讨种群更新 问题, 至于发生于区域尺度的可利用生境限制应该 纳入涵义更为宽泛的更新限制中(图1)。

\section{2 补充限制理论}

植物种群生态学中最早有关补充限制的研究可 追溯到20世纪60、70年代, 如Sagar和Harper (1960)、 Putwain等(1968)关于微生境限制的报道, Hawthorn 和Cavers (1976)、Greig-Smith和Sagar (1981)关于种 源限制的报道。Crawley (1990)对植物种群动态进行 了归纳总结, 指出微生境限制是影响种群更新的首 要因素。Eriksson和Ehrlén (1992)在前人工作的基础 上, 采用播种实验对瑞典针叶-落叶阔叶林生态系 统的14种植物的种群更新进行了验证性研究, 结果 发现种源限制的有3种, 种源和微生境共同限制的 有6种, 限制因素不明确的有5种, 并认为在森林生 态系统中, 种源限制的作用被低估了, 这与Crawley (1990)的观点是不一致的。目前, 补充限制理论已被 广泛用于解释植物种群更新及其空间分布格局, 在 生产实践上如退化植被生态恢复方面也有大量应用 (Slodowicz et al., 2019)。本文主要综述微生境限制 和种源限制以及扩散限制相关领域的研究进展情况, 也对地下芽库与无性繁殖在种群更新中的作用进行 了初步论述, 这是种源限制研究的一个薄弱领域。 此外, 尽管补充限制与植物群落物种多样性分布、 


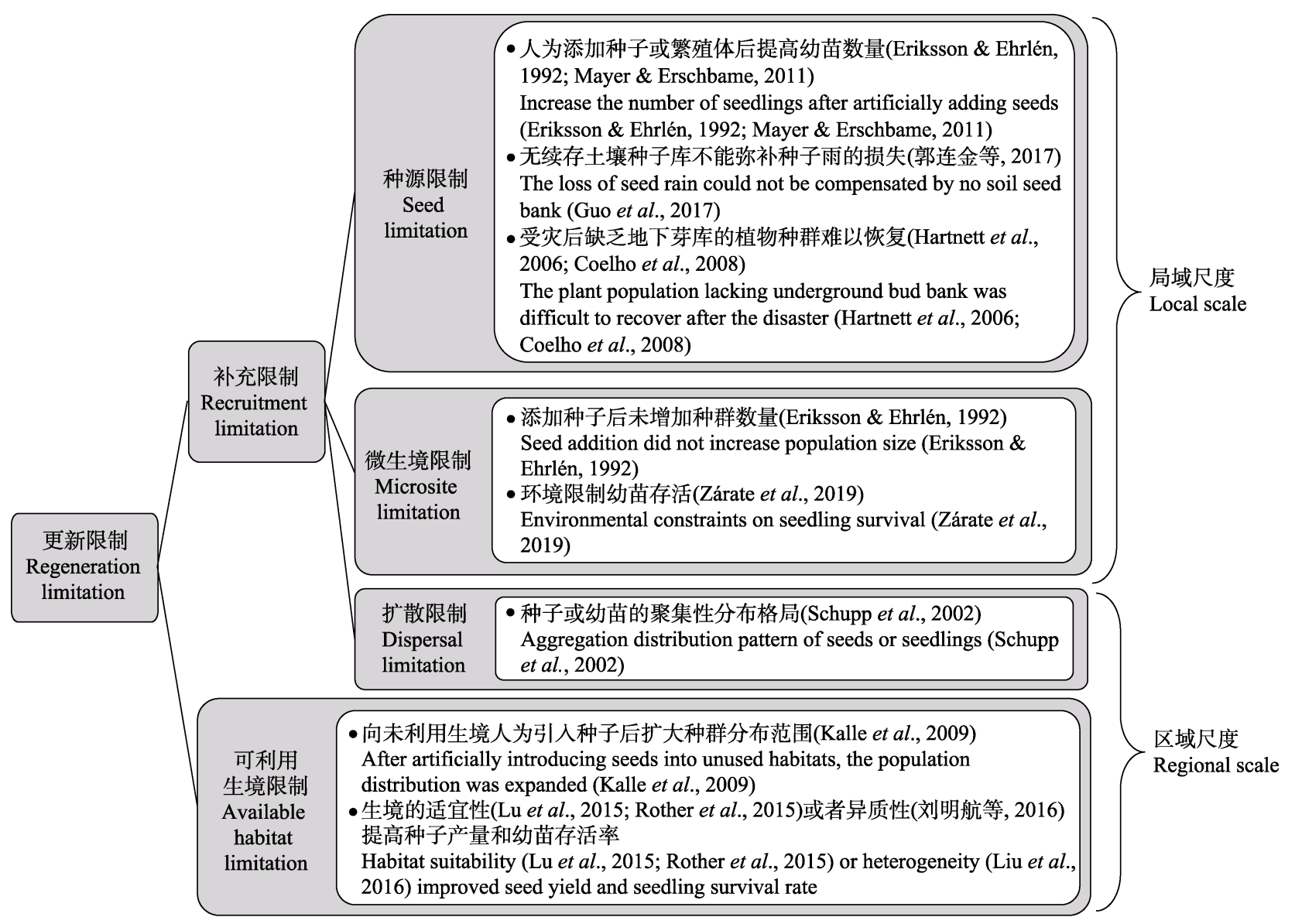

图1 植物种群更新研究中常用术语及其基本内涵的界定。

Fig. 1 Definition of common terms and their basic connotations in plant population regeneration.

维持机制等理论问题联系紧密, 但本文主要限于种 群水平进行论述。

\section{1 种源限制}

与微生境限制相比, 种源限制在植物种群更新 中更具有普遍性(Ehrlén et al., 2006; Rey et al., 2006)。种源限制的产生主要与种子生产、土壤中种 子库和芽库中的繁殖体数量不足有关。

\subsection{1 种子生产}

就种子生产而言，容易产生种源限制的植物类 群大体具有以下特点: 演替的先锋物种(Turnbull et al., 2000) 以及具短命 (Crawley, 1990)、大种子 (Turnbull et al., 1999; 王哲等, 2005; Clark et al., 2007)或短寿种子(Clark et al., 2007)等特征的植物。 另外, 与大尺度相比, 在较小的空间尺度上容易发 生种源限制(Uriarte et al., 2010); 与草地相比, 森林 更容易发生种源限制(Crawley, 1990; Eriksson \& Ehrlén 1992; Clark et al. 1999; Turnbull et al., 2000); 与稳定生境相比, 干扰的生境更容易发生种源限制 (Clark et al., 2007), 但是干扰引起的种子限制对种
群更新的影响与种子数量有关系, 如果种子数量足 够, 干扰的作用可能会很小, 而在种子有限的情况 下，这种影响最大(Calviño-Cancela, 2007)。

产生种源限制的原因主要有以下方面: 1)种子 产量的年际变异性。气候总是波动的, 由此导致种 子产量呈现年际变异性。热带稀树草原上的树种 Acacia mellifera种群种子产量受降水量影响, 进而 出现种源限制 (Joubert et al., 2013)。Solbreck和 Knape (2017)的研究也表明多年生草本植物的种子 生产与当前夏季的降水以及前一年种子生产存在非 线性相关性。更为极端的年际变异是丰产(masting) 现象, 这些树种大多数年份产生很少甚至不产生种 子, 而在一些年份中产生大量种子。通常认为丰产 现象有利于种群更新(Ascoli et al., 2015), 因为丰产 会降低种子被捕食比例, 也就是种子产量与捕食率 为负相关, 这被称为捕食者饱和假说(predator satiation hypothesis)(Bogdziewicz et al. 2018)。2)对于自 然种群, 如果不具有持久种子库, 地上种子雨的作 用就异常重要了。Clements和Bierzychudek (2017) 
对美国俄勒冈州的3个森林片段研究发现, 尽管许 多森林物种不具有持久种子库, 但可依靠每年的种 子雨实现种群更新。在这种情况下, 一旦地上种子 雨减少, 就极容易发生种源限制。但是如果具有持 久种子库, 地上种子雨对种群更新的作用就很难评 估, 这类种群动态往往会表现出较大的波动, 形成 较大的时间方差。3)动物捕食。种子从母株散布后 将不可避免地受到动物捕食, 从而产生种源限制 (Fischer et al., 2015)。但是, 捕食不仅发生在扩散阶 段之后, 同样也发生在扩散之前, 即在母株上就已 经发生捕食, 称为扩散前种子捕食 (pre-dispersal seed predation, PDSP)。在森林生态系统中, PDSP普 遍存在于木本植物中, 种子生产-种子捕食者系统 对种群更新的进化适应策略的影响是该领域关注的 焦点。Xu等(2015)发现群落中优势种与稀有种的种 子生产机制存在差异, 优势种常出现捕食者饱食效 应, 而稀有种采用了一种独特的“躲猫猫”策略来降 低PDSP风险。Moreira等(2016)研究表明种子生产种子捕食者系统进化受种子产量驱动, 在海岸松 (Pinus pinaster)种群中, 捕食者的饱食效应在丰产 年份中随种子产量而增加, 而捕食者饱食效应的增 加又有利于提高普通年份的种子产量。实际上, 种 子生产-捕食者系统的进化动力学特征体现了更为 一般意义上的植物-动物协同进化关系。

\subsection{2 土壤种子库}

由于土壤中储存了大量的种子, 土壤种子库常 被视为植物种群更新的保险库, 与地上部种子雨共 同促进种群的更新, 能够形成持久性土壤种子库的 植物, 土壤种子库的作用更为重要(Clements \& Bierzychudek 2017)。土壤种子库在种群更新中的作 用取决于种子的死亡率(Martinez-Ramos \& AlvarezBuylla, 1995)和萌发率两个方面, 其中死亡率来自 于动物捕食和病菌侵染而导致的生活力下降或腐烂, 而萌发率取决于种子的休眠特性。

如果种子寿命短, 而土壤种子库又损耗严重, 将会导致种群更新受阻, 如郭连金等(2017)研究发 现, 香果树(Emmenopterys henryi)种群更新障碍在 于其种子微小且寿命短, 土壤种子库中虫蛙和腐烂 种子比例在埋藏1个月后达到 $78.25 \%$ 。张玉波等 (2005)研究发现, 胡杨(Populus euphratica)种子散布 到地面后6-40天即有 $95 \%$ 的种子丧失活力, 从而影 响种群更新。可见, 土壤种子库在种子死亡率高的
情况下, 对种群更新的贡献很小。

即使土壤种子库很大, 如果绝大部分种子处于 休眠状态或埋藏于土壤深层, 仍会限制种群更新。 休眠作为植物种子的固有特性, 其实质是延迟繁殖 时间，从而在多个季节或年份间萌发，就此而言， 可视为一种时间上的散布。如在干旱环境中的植物 种子往往具有休眠特性, 且可在多个季节萌发, 显 示出萌发异型性(germination heteromorphism), 提 高总体幼苗存活率(Koyama, 1998), 而在湿润环境 中, 或者主要在雨季散布的种子, 则往往不具有休 眠特性。如Salazar等(2011)等研究发现, 热带稀树草 原中, 旱季散布的种子大多具休眠特性, 并且水分 含量低, 而湿季散布的种子大多无休眠现象, 并且 水分含量高, 由此影响种子萌发和幼苗更新情况。 因此, 休眠是影响土壤种子库有效性的重要因素, 但不同物种的休眠原因不同, 既有生理原因, 如低 温、光照、水分、后熟作用, 也有生态原因, 如埋藏 深度和大型土壤动物的搬运, 需要采取相应方式打 破休眠促进植物种群更新。

\subsection{3 地下芽库与无性繁殖}

植物种群更新不仅体现在种子和有性繁殖上, 地下芽库及其产生的无性分株对于种群更新同样具 有重要意义(杨允菲和李建东, 1996; 李海燕和杨允 菲, 2011; Seabloom, 2011; 韩大勇等, 2019), 甚至在 特定条件下更为重要, 体现在分株比实生苗在干扰 后具有更强的恢复能力(补偿生长)(Hartnett et al., 2006; Coelho et al., 2008)和对干扰的抵抗能力(生理 整合)(杨允菲等, 2005)。

地下芽库和无性繁殖对植物种群更新的作用受 到环境、生物和干扰等多重因素的制约。在土壤含 水量增加(焦德志等, 2015; Qian et al., 2017), 养分 充足(张俊菲等, 2018)等情况下, 地下芽数量增加, 种群倾向于通过无性繁殖方式维持更新。在生物影 响因素方面, 随着种间竞争强度的增加, 会降低有 性繁殖, 增加无性繁殖(侯真珍等, 2013; Titus \& Bishop, 2014), 而随着种内竞争强度的增加, 则以 产生种子的有性繁殖为主, 降低无性繁殖对种群更 新的贡献(Ikegami et al., 2012; 侯真珍等, 2013; Xie et al., 2014)。

除了环境和生物因素, 干扰对芽库和无性繁殖 的影响也受到较多关注。在干扰因子中, 放牧干扰 研究得最多, 适度的放牧干扰有利于增加地下芽的 
数量和地上部分的分藥密度、分枝数量以及无性繁 殖分配，过度放牧则具有抑制作用(Dalgleish et al., 2012; 赵凌平等, 2016; 崔伟等, 2017; 古琛等, 2017; Wang et al., 2017)。火是另一个重要的干扰因子, 多 见于森林和草原生态系统中。由于地下芽位于土壤 之中, 在火烧干扰后存活率高于地上芽, 在种群更 新中具有更为重要的作用(Pausas et al., 2018)。火烧 对地下芽库的影响与发生时间(Russell \& Vermeire, 2015)、频率(Benson et al., 2004; Dalgleish \& Hartnett, 2009)、强度(李安定等, 2014) 以及物种的生活型 (Dalgleish \& Hartnett, 2009)有关。

\section{2 扩散限制}

扩散限制是产生的种子无法散布到合适的生境 而影响种群幼苗的补充。就一般意义而言, 不论风 媒传播还是动物传播(包括二次搬运), 都会导致种 子或幼苗局限于母树周围呈聚集性分布(Clark et al., 1999), 因此, 不论种群还是群落水平, 扩散限制是 普遍存在的, 差别只在于限制程度不同。以往在种 群和群落水平上进行种子添加或者种子雨监测实验 已有大量报道, 包括热带雨林(Dalling et al., 2002), 温带森林草本群落(Ehrlén \& Eriksson, 2000; Rey et al., 2006)等各种植被类型, 但是这类实验并不能解 释为什么会产生扩散限制。

一般来说, 扩散限制与种子产量(种子雨)、种子 扩散方式与能力以及传播媒介有关。比如在种子丰 产年份中, 种子产量的增加提高了种子散布比例, 其原理可以用同胞竞争(sibling competition)假说解 释, 即种子产量增加的时候, 需要增加散布比例从 而减少同胞后代在母株附近的竞争, 避免降低母株 适合度(Cheplick, 1992)。依靠动物传播的种子则依 赖于动物种类(la Mantia et al., 2019)、数量(Caughlin et al., 2015)以及动物行为(Schupp et al., 2000)。

在热带雨林生态系统中, 由于捕食者或者病原 菌以母株为食, 而种子或幼苗又常在母株附近呈聚 集性分布, 导致这些子代种群容易受害而发生更新 限制, Janzen (1970)和Connell (1971)最先提出模型 描述母株附近的种子和幼苗密度依赖性的被捕食现 象。根据该模型(现在常被称为J-C模型), 幼苗的存 活率和逃避捕食的概率都随着散布距离的增加而增 加, 因此幼苗存活率是种子散布距离和逃避捕食概 率的函数。J-C模型表明, 扩散后的种子和幼苗存活 率与密度依赖性捕食有关, 同时, PSDP理论表明种
子扩散前的捕食者饱食效应同样会影响种子的存活 率和扩散率。由此带来的问题是, 二者之间存在何 种的内在联系, 这可从最近的一些研究得到部分答 案。Xiao等(2017)研究发现, 枹栋(Quercus serrata) 种群在高密度下可通过增加捕食者饱食而减少虫害 对幼苗的侵袭, 但是在单个树木中, 则符合J-C模型 的预测，说明捕食者饱食效应限制了枹柇种群中 J-C效应的发生。Bogdziewicz等(2018)的研究则表明, 当捕食者能够在不同植株之间迁移时，将导致捕食 压力进行再分配, 同样会改变J-C效应, 降低高密度 种群的捕食压力。因此, 扩散和捕食可能共同影响 植物的适合度。

另外, 扩散限制和微生境限制是紧密联系的两 个过程, 在理解种群补充限制问题时不应该将二者 割裂。根据 de la Peña-Domene和 Martínez-Garza (2018)的研究, 考虑幼苗密度加权的扩散限制指数 显著高于未加权的, 表明幼苗的扩散限制存在较强 的密度依赖效应。另一项研究也发现, 即使不存在 扩散限制, 但是幼苗较高的密度依赖性死亡仍限制 了种群更新(Rand et al., 2020)。还有来自Luo等(2013) 的报道, 风散布型植物能够产生大量小种子, 不存 在扩散限制, 能够形成较大的幼苗种群, 但是在微 生境限制下, 幼苗种群死亡率很高, 说明种子密度 所带来的更新收益被幼苗的高死亡率所抵消。综上, 密度依赖性幼苗存活(死亡)是评估扩散限制的作用 时需要考虑的一个重要方面, 因为扩散的目的是产 生更多的种群, 增加母株适合度, 如果幼苗存活率 低, 则扩散毫无意义, 就此而言, 种子扩散存在进 化稳定对策。

\section{3 微生境限制}

\subsection{1 非生物环境}

微生境限制作为植物种子扩散的后续过程, 主 要影响植物种子萌发和幼苗的存活, 诸如土壤水 分、养分、调落物等。因此, 微生境限制的作用程 度, 或者说对补充限制的贡献大小与环境质量、物 种生态学特性有关。一般而言, 在以下情况下更容 易发生微生境限制: 1)河岸带(Fraaije et al., 2015)、 沼泽(Mayer \& Erschbamer, 2011)等环境梯度强烈的 区域容易发生微生境限制。2)逆境。如干旱降低幼 苗萌发率和生长(García-Fayos \& Gasque, 2006); 灌 木遮阴导致的光竞争也会影响下层草本植物种群更 新, 从而发生微生境限制(Calviño-Cancela, 2007)。 
3)产生小种子的植物种群, 因为小种子对环境利用 能力和抵抗力较差(García-Meza \& Martorell, 2016)。 4)一年生植物(García-Meza \& Martorell, 2016)。

与种源限制不同, 非生物环境对植物种群更新 的影响发生于多个生活史阶段, 并且作用程度随之 变化。如土壤水分作为种子萌发和幼苗建成的必要 条件, 适宜的水分在种群的初期阶段能够促进种子 萌发和生长(赵高卷等, 2016)。但是, 水分的作用持 续时间短, 尽管可以提高种子萌芽率和幼苗成活率, 但对后续的更新过程影响很小(Zimmermann et al., 2008), 需要在更长的时间尺度上评价水分的作用。 土壤养分对幼苗的作用也随幼苗的年龄变化而变化 (Record et al., 2016), 如伊犁河谷镰叶锦鸡儿(Caragana aurantiaca)幼苗数量在低龄时与土壤氮含量相 关, 而在高龄时与磷含量相关(韩大勇等, 2019)。调 落物也表现出类似的规律, 研究发现, 地表调落物 对硬斗石栋(Lithocarpus hancei)种子存活有积极影 响, 但对幼苗建成没有影响(Hu et al., 2016)。 Molofsky等(2000)的研究则进一步表明, 调落物不 仅影响初期植物种子萌发和幼苗存活, 还降低后期 种群生物量, 从而对种群动态产生潜在的持续影 响。另外一项持续5年的实验表明, 调落物对幼苗存 活率在前 2 年影响较小甚至是负效应, 但是从第 5 年 开始, 调落物显著提高了幼苗存活率(Urretavizcaya \& Defossé, 2013)。

微生境限制产生的生态学机理主要体现在影响 种子的活力、萌发性、幼苗的存活力、物质分配等 方面, 具体表现为: 1)影响幼苗的生物量分配格局, 如在高养分土壤上生长的幼苗分配给根系的养分较 少, 而分配给光合组织的养分较多(Palow \& Oberbauer, 2009); 2)在化学计量特征上, 氮的添加降低 了叶片碳氮比, 磷的添加则增加了根系的碳分配 (Cárate-Tandalla et al., 2015); 3)土壤养分的增加通 过促进无性繁殖增加了幼苗的整体生长和分真数, 提高存活率(Lee et al., 2018); 4)调落物对种子萌发 和幼苗存活的影响主要包括: 化感作用(马冬雪和 刘仁林, 2016; Halvorson et al., 2017), 机械隔离(周 艳等, 2015), 遮阴(周艳等, 2015)和增加幼苗感染真 菌的机会(Hu et al., 2016)。

\subsection{2 生物环境}

无论种内竞争(密度制约)(Vilà et al., 2006)还是 种间竞争(Duclos et al., 2013), 竞争强度的增加均会
降低幼苗的存活率，尤其地上竞争的影响更大 (Ding et al., 2016), 但是竞争对幼苗建成和生长的 影响受环境因子和空间尺度制约, 在土壤水分充足 (Lucas-Borja et al., 2016)或者土壤肥沃(Gavinet et al., 2016)的条件下, 种间竞争对幼苗存活的影响很 小甚至不存在, 而只在严酷生境中才显得很重要。

动物的牧食作用对幼苗存活率也有显著影响, 但是结论并不一致。哺乳动物(如旅鼠(Lemmus sp.) 和驯鹿(Rangifer tarandus))的自然放牧有利于物种 的定殖和幼苗萌发(Eskelinen \& Virtanen, 2005)。而 其他研究则表明, 蛞蝓(Agriolimax agrestis)对种子 萌发和幼苗形成都有负面影响(Kupferschmid et al., 2000; Overbeck et al., 2003)。

\section{4 补充限制研究方法概述}

对于单个种群, 种子添加实验是确定种源限制 和微生境限制的最有效方法(Turnbull et al., 2000; Münzbergová \& Herben, 2005)。种子添加实验大致 分为两类: 一类称为种子补充实验(seed augmentation), 即把种子添加入现有种群中, 第二类是种子 引入实验(seed introduction), 即把种子播种于新的、 无该种群分布的生境。按此标准, 大约 $50 \%$ 的种子 补充实验表现出种子限制。在判断补充限制类型时, 可依据如下方法: 如果添加种子后, 显著提高了幼 苗数, 则认为存在种源限制, 如果未显著提高, 则 存在微生境限制(Eriksson \& Ehrlén, 1992)。种源限 制也可以用公式量化(Clark et al., 2013):

$$
E_{i}=\frac{\left(E_{\mathrm{EXP}, i}-E_{\mathrm{CONT}, i}\right)}{S_{\mathrm{AUG}, i}}
$$

式中, $E_{i}$ 为种源限制效应, $E_{\mathrm{EXP}, i}$ 和 $E_{\mathrm{CONT}, i}$ 分别为种子 添加前后的幼苗数, $S_{\mathrm{AUG}, i}$ 为添加的种子数, $i$ 为处 理数。

至于种源限制和微生境限制的共同作用的情况， 一般需要设置额外的实验来验证, 如同时添加种子 和干扰处理, 如果幼苗数在两种处理下均显著增加, 则可认为两个因素同时起作用(Eriksson \& Ehrlén, 1992)。当然，此处的干扰必须是有利于种子萌发的 干扰, 如减少调落物覆盖、改善光照条件、施肥等 (Münzbergová \& Herben, 2005)。另外, 也可以增加 实验处理梯度, 进行回归分析。如果种子添加量与 幼苗数之间为非线性关系, 那么可以认为同时存在 种源限制和微生境限制 (Münzbergová \& Herben, 2005)。不过Clark等(2007)建议, 在进行种子添加实 
验之前, 最好先调查土壤种子库情况。

\section{3 展望}

总体而言, 以往关于种群更新补充限制研究的 不足之处主要体现在涉及的限制因子仅为 1 种或 2 种, 很少有 2 种以上的; 在研究的持续时间上, 大多为 $1-2$ 年, 很少超过 3 年, 但有 1 项研究持续了 11 年 (Ehrlén et al., 2006); 在研究内容上, 侧重不同限制 过程的相对作用的验证性研究, 而对明确量化种源 限制及相关生态过程的机理性研究不够深入。笔者 认为以后一段时间内应加强以下几个方面的研究。

\section{1 开展长期实验, 正确、客观评价各种限制机制} 的相对作用

补充限制的实质是各种因素在不同的生活史阶 段、不同环境条件以及不同生活型植物中的相对重 要性的问题, 其原理是生态因子作用的阶段性特 征。比如, 尽管种源限制对植物种群更新具有重要 影响, 但是, 由于生命现象的非线性特点, 种源限 制不一定必然导致种群更新不良, 二者之间不是一 一对应的关系, 即使消除了种源限制, 大量的幼苗 萌发后也可能会因为密度制约而死亡, 影响更新。 已有研究表明种子的相对重要性随着种子密度、幼 苗密度和时间变化而变化(Clark et al., 2007, 2013; Zimmermann et al., 2008)。因此, 补充限制作用于多 个生活史阶段(Marques \& Burslem, 2015), 有必要 进行长期的实验, 以便正确、客观地评价各种限制 因素的相对作用, 得出更为可靠的结论。

\section{2 种子生态学也许是沟通种源限制和微生境限} 制研究的一座桥梁

以往研究对于种源限制和微生境限制在种群更 新中的作用的结论并不一致，其原因在于二者之间 不是对立的关系, 因为两者都可能与物种的同一功 能性状有关(Marteinsdóttir, 2014), 比如种子大小, 因为无论种子产量、扩散、在土壤中的续存时间、 萌发能力、幼苗存活力, 都与种子大小有关(Vaughton \& Ramsey, 2001), 并且, 种子大小作为一个相 对稳定的功能性状, 其效应会一直持续到生长后期 阶段。目前还缺乏整合种子数量、大小、附属物等 性状对幼苗存活、生长和繁殖等后续过程的影响研 究(Jiménez-Alfaro et al., 2016; Larson \& Funk, 2016; 张红香和周道玮, 2016; Rosin \& Poulsen, 2018), 需 要补充和加强, 这有可能将种源限制和微生境限制
有机地整合起来。

\section{3 加强多因子综合实验研究}

不同的环境因子之间相互干扰或拮抗，而生物 因子的效应, 如调落物、种内或种间竞争, 又往往为 环境因子所掩盖(Gavinet et al., 2016; Lucas-Borja et al., 2016), 进行单因子实验是无法得出客观结论的, 需要开展涵盖非生物和生物多因子的综合性实验。

\section{4 加强地上种子生产和地下种子库及芽库的耦 合研究}

与地上相比, 土壤种子库与芽库在种群更新研 究中仍显薄弱, 应加强地上种子生产与土壤种子库 和芽库的耦合研究, 围绕种子产量、土壤种子库、 幼苗库、芽库以及种群大小之间的数量关系, 定量 化阐述各种因素在种群更新中的相对作用。这里有 两个关键科学问题需要解决: 一是需要探明土壤种 子库内种子的聚集性空间分布格局(由散布方式导 致的), 这是进行该方面研究的基础, 也是目前了解 的最少的; 二是在具有持久种子库的种群中, 如何 将种子雨在种群动态中的作用剥离出来, 目前还没 有很好的研究方法。

\section{5 着重加强种源限制及相关生态过程的进化与 生态相结合的机理性研究}

尽管以往就植物种群的种源限制的涵义和生态 后果开展了大量研究, 但大多停留在 “就事论事” 层 面, 没有深入探讨为什么植物会存在种源限制, 即 种源限制是否是物种的一种稳固进化特性, 而与生 态学过程无关。如与草本植物相比, 木本植物普遍 存在种源限制(Crawley, 1990; Turnbull et al., 2000), 这实际上就是物种进化适应对策差异的体现。因此, 尽管与种子大小相比, 种子数量的稳定性较差, 但 是, 弄清种子数量在多大程度上是进化稳定的, 去 除物种的进化“惯性”, 种源限制在多大程度上是单 纯由环境或生物因素引起的, 即种源限制的纯效应, 是令人感兴趣的科学问题。Lu等(2015)报道的系统 发育相关性对中国中部亚热带森林幼苗存活的影响 就是这方面的一个例子。因此, 有必要拓展种源限 制的系统发生独立性比较 (phylogenetically independent contrast analysis, PIC)研究, 将引起种子产 量变异的来源分解为进化、环境和生物几个方面并 进行定量化分析, 进而结合种群大小、年龄结构和 种群增长率等多个参数开展进化与生态相结合的机 理性研究, 可能是突破现有理论框架的一个方向。 
总之, 种群更新的补充限制研究绝不是哪个过 程更重要的简单实验验证, 而是要在进化、适应的 背景下将生活史性状与种群更新问题有机地联系起 来, 除了拓展种源限制的系统发生独立性研究之外, 其他如种子生产-捕食者系统进化、种子产量-散布 率的进化稳定对策、土壤种子库的遗传多样性等也 是需要加强的方面, 从而对种群更新问题得出更为 深刻的认识和理解, 建立更为综合、系统的种群更 新补充限制理论体系。

\section{参考文献}

Ascoli D, Vacchiano G, Maringer J, Bovio G, Conedera M (2015). The synchronicity of masting and intermediate severity fire effects favors beech recruitment. Forest Ecology and Management, 353, 126-135.

Barrett JP, Silander Jr JA (1992). Seedling recruitment limitation in white clover (Trifolium repens; Leguminosae). American Journal of Botany, 79, 643-649.

Benson EJ, Hartnett DC, Mann HK (2004). Belowground bud banks and meristem limitation in tallgrass prairie plant populations. American Journal of Botany, 91, 416-421.

Bogdziewicz M, Espelta JM, Muñoz A, Aparicio JM, Bonal R (2018). Effectiveness of predator satiation in masting oaks is negatively affected by conspecific density. Oecologia, 186, 983-993.

Callaway RM (1992). Effect of shrubs on recruitment of Quercus douglasii and Quercus lobata in California. Ecology, 73, 2118-2128.

Calviño-Cancela M (2007). Seed and microsite limitations of recruitment and the impacts of post-dispersal seed predation at the within population level. Plant Ecology, 192, 35-44.

Cárate-Tandalla D, Leuschner C, Homeier J (2015). Performance of seedlings of a shade-tolerant tropical tree species after moderate addition of $\mathrm{N}$ and P. Frontiers in Earth Science, 3, 75. DOI: 10.3389/feart.2015.00075.

Caughlin TT, Ferguson JM, Lichstein JW, Zuidema PA, Bunyavejchewin S, Levey DJ (2015). Loss of animal seed dispersal increases extinction risk in a tropical tree species due to pervasive negative density dependence across life stages. Proceedings of the Royal Society B: Biological Sciences, 282, 20142095. DOI: 10.1098/rspb.2014.2095.

Cheplick GP (1992). Sibling competition in plants. Journal of Ecology, 80, 567-575.

Clark CJ, Poulsen JR, Levey DJ (2013). Roles of seed and establishment limitation in determining patterns of afrotropical tree recruitment. PLOS ONE, 8, e63330. DOI: 10.1371/journal.pone.0063330.

Clark CJ, Poulsen JR, Levey DJ, Osenberg CW (2007). Are plant populations seed limited? A critique and meta-analysis of seed addition experiments. The American Naturalist, 170, 128-142.

Clark JS, Silman M, Kern R, Macklin E, HilleRisLambers J (1999). Seed dispersal near and far: patterns across temperate and tropical forests. Ecology, 80, 1475-1494.

Clements H, Bierzychudek P (2017). Can the persistent seed bank contribute to the passive restoration of urban forest fragments after invasive species removal? Ecological Restoration, 35, 156-166.

Coelho FF, Capelo C, Figueira JEC (2008). Seedlings and ramets recruitment in two rhizomatous species of Rupestrian grasslands: Leiothrix curvifolia var. lanuginosa and Leiothrix crassifolia (Eriocaulaceae). Flora-Morphology, Distribution, Functional Ecology of Plants, 203, 152-161.

Connell JH (1971). On the role of natural enemies in preventing competitive exclusion in some marine animals and in rain forest trees//Den Boer PJ, Gradwell GR. Dynamics of Populations. Centre for Agricultural Publishing and Documentation, Wageningen, the Netherlands. 298-312.

Crawley MJ (1990). The population dynamics of plants. Philosophical Transactions of the Royal Society of London Series B: Biological Sciences, 330, 125-140.

Cui W, Zhao LP, Zhao FR (2017). Effects of fencing and grazing management on bud bank in a semiarid steppe on the Loess Plateau. Pratacultural Science, 34, 9-15. [崔伟, 赵 凌平, 赵芙蓉 (2017). 封育和放牧对黄土高原典型草原 芽库的影响. 草业科学, 34, 9-15.]

Dalgleish HJ, Hartnett DC (2009). The effects of fire frequency and grazing on tallgrass prairie productivity and plant composition are mediated through bud bank demography. Plant Ecology, 201, 411-420.

Dalgleish HJ, Ott JP, Setshogo MP, Hartnett DC (2012). Interspecific variation in bud banks and flowering effort among semi-arid African savanna grasses. South African Journal of Botany, 83, 127-133.

Dalling JW, Muller-Landau HC, Wright SJ, Hubbell SP (2002). Role of dispersal in the recruitment limitation of neotropical pioneer species. Journal of Ecology, 90, 714-727.

de la Peña-Domene M, Martínez-Garza C (2018). Integrating density into dispersal and establishment limitation equations in tropical forests. Forests, 9, 570. DOI: 10.3390/ f9090570.

Ding Y, Zang RG, Letcher SG, Liu WD, Lu XH (2016). Aboveground and belowground competition affect seedling performance and allometry in a tropical monsoon forest. New Forests, 47, 529-540.

Duclos V, Boudreau S, Chapman CA (2013). Shrub cover influence on seedling growth and survival following logging of a tropical forest. Biotropica, 45, 419-426.

Ehrlén J, Eriksson O (2000). Dispersal limitation and patch occupancy in forest herbs. Ecology, 81, 1667-1674.

Ehrlén J, Münzbergová Z, Diekmann M, Eriksson O (2006).

www.plant-ecology.com 
Long-term assessment of seed limitation in plants: results from an 11-year experiment. Journal of Ecology, 94, 1224-1232.

Eriksson O, Ehrlén J (1992). Seed and microsite limitation of recruitment in plant populations. Oecologia, 91, 360-364.

Eskelinen A, Virtanen R (2005). Local and regional processes in low-productive mountain plant communities: the roles of seed and microsite limitation in relation to grazing. Oikos, 110, 360-368.

Fischer C, Kollmann J, Wagner TC (2015). How does the seed fate of Crotalaria podocarpa DC, a highly competitive herbaceous legume in arid rangelands, contribute to its establishment probability? Perspectives in Plant Ecology, Evolution and Systematics, 17, 405-411.

Fraaije RGA, ter Braak CJF, Verduyn B, Verhoeven JTA, Soons MB (2015). Dispersal versus environmental filtering in a dynamic system: drivers of vegetation patterns and diversity along stream riparian gradients. Journal of Ecology, 103, 1634-1646.

García-Fayos P, Gasque M (2006). Seed vs. microsite limitation for seedling emergence in the perennial grass Stipa tenacissima L. (Poaceae). Acta Oecologica, 30, 276-282.

García-Meza D, Martorell C (2016). A trade off in the absolute magnitudes of seed and microsite limitations and their effects on population regulation. Oikos, 125, 308-314.

Gavinet J, Prévosto B, Fernandez C (2016). Do shrubs facilitate oak seedling establishment in Mediterranean pine forest understory? Forest Ecology and Management, 381, 289-296.

Greig-Smith J, Sagar GR (1981). Biological causes of rarity in Carlina vulgaris//Synge H. Biological Aspects of Rare Plant Conservation. Wiley, Chichester. 389-400.

Gu C, Zhao TQ, Wang YT, Wang X, Jia LX, Zhao ML (2017). The response of growth and reproduction for Stipa breviflora to different stocking rates. Ecology and Environmental Sciences, 26, 36-42. [古琛, 赵天启, 王亚婷, 王 坌, 贾丽欣, 赵萌莉 (2017). 短花针茅生长和繁殖策略 对载畜率的响应. 生态环境学报, 26, 36-42.]

Guo LJ, Cao HW, Xu WH, Tian YQ, Xiao ZP (2017). Seed rain, soil seed bank and quantitative dynamics of seedlings of Emmenopterys henryi populations in different altitude regions. Bulletin of Botanical Research, 37, 377-386. [郭 连金, 曹吴玮, 徐卫红, 田玉清, 肖志鹏 (2017). 香果 树(Emmenopterys henryi) 种群种子雨、种子库及实生苗 数量的海拔梯度变化. 植物研究, 37, 377-386.]

Halvorson JJ, Belesky DP, West MS (2017). Inhibition of forage seed germination by leaf litter extracts of overstory hardwoods used in silvopastoral systems. Agroforestry Systems, 91, 69-83.

Han DY, Zhao Y, Ahan J, Zhang W, Yang YF (2019). Age structure of Caragana aurantiaca young populations in the Yili valley, Xinjiang. Chinese Journal of Ecology, 38,
3601-3608. [韩大勇, 赵玉, 贾娜尔・阿汗, 张维, 杨允菲 (2019). 新疆伊犁河谷镰叶锦鸡儿(Caragana aurantiaca)幼株种群年龄结构. 生态学杂志, 38, 3601-3608.]

Hartnett DC, Setshogo MP, Dalgleish HJ (2006). Bud banks of perennial savanna grasses in Botswana. African Journal of Ecology, 44, 256-263.

Hawthorn WR, Cavers PB (1976). Population dynamics of the perennial herbs Plantago major L. and P. rugelii Decne. The Journal of Ecology, 64, 511-527.

Hou ZZ, He S, Wang FL, Zhang AQ (2013). Dynamics of rare clonal plant Linnaea borealis L. sexual reproduction and related affecting factors. Chinese Journal of Ecology, 32, 3167-3172. [侯真珍, 何爽, 王风雷, 张爱勤 (2013). 珍 稀克隆植物北极花有性繁殖动态及影响因素. 生态学 杂志, 32, 3167-3172.]

Hu JJ, Luo CC, Turkington R, Zhou ZK (2016). Effects of herbivores and litter on Lithocarpus hancei seed germination and seedling survival in the understorey of a high diversity forest in SW China. Plant Ecology, 217, 1429-1440.

Ikegami M, Whigham DF, Werger MJA (2012). Effects of local density of clonal plants on their sexual and vegetative propagation strategies in a lattice structure model. Ecological Modelling, 234, 51-59.

Janzen DH (1970). Herbivores and the number of tree species in tropical forests. The American Naturalist, 104, 501-528.

Jiao DZ, Yao L, Huang ZY, Yang YF (2015). Bud population dynamics of Phragmites australis in heterogeneous habitats of Northeast grassland, China. Chinese Journal of Applied Ecology, 26, 404-410. [焦德志, 么璐, 黄晊月, 杨 允菲 (2015). 东北草地异质生境芦苇芽种群动态. 应用 生态学报, 26, 404-410.]

Jiménez-Alfaro B, Silveira FAO, Fidelis A, Poschlod P, Commander LE (2016). Seed germination traits can contribute better to plant community ecology. Journal of Vegetation Science, 27, 637-645.

Joubert DF, Smit GN, Hoffman MT (2013). The influence of rainfall, competition and predation on seed production, germination and establishment of an encroaching Acacia in an arid Namibian savanna. Journal of Arid Environments, 91, 7-13.

Kalle H, Ari-Pekka H, Pasi R, Juha T (2009). Seed introduction and gap creation facilitate restoration of meadow species richness. Journal for Nature Conservation, 17, 236-244.

Koyama H (1998). Seed heteromorphism and timing of germination, their mechanisms and adaptive significance. Japanese Journal of Ecology, 48, 129-142.

Kupferschmid AD, Stampfli A, Newbery DM (2000). Dispersal and microsite limitation in an abandoned calcareous grassland of the southern prealps. Folia Geobotanica, 35, 125-141.

la Mantia T, Rühl J, Massa B, Pipitone S, Lo Verde G, Bueno RS (2019). Vertebrate-mediated seed rain and artificial 
perches contribute to overcome seed dispersal limitation in a Mediterranean old field. Restoration Ecology, 27, 1393-1400.

Larson JE, Funk JL (2016). Regeneration: an overlooked aspect of trait-based plant community assembly models. Journal of Ecology, 104, 1284-1298.

Lee EH, Lee BE, Kim JG (2018). Effects of water levels and soil nutrients on the growth of Iris laevigata seedlings. Journal of Ecology and Environment, 42, 5. DOI: 10.1186/s41610-018-0065-4.

Li AD, Peng X, Zhang JL (2014). Study on plant regeneration bank in burned land after forest fire in karst areas. Guizhou Science, 32, 40-46. [李安定, 彭熙, 张建利 (2014). 喀斯 特山区森林火灾后火烧迹地植物更新库研究. 贵州科 学, 32, 40-46.]

Li HY, Yang YF (2011). Age structures of Spodiopogon sibiricus populations on weedy meadow and elm woodland in Songnen Plain, Northeast China. Chinese Journal of Applied Ecology, 22, 1982-1986. [李海燕, 杨允菲 (2011). 松嫩平原杂类草草甸和榆树疏林草原大油芒种群的年 龄结构. 应用生态学报, 22, 1982-1986.]

Liu MH, Ye J, Wen B (2016). Seed germination and seedling survival of Baccaurea ramiflora and Saprosma ternata in Xishuangbanna tropical rainforests under habitat heterogeneity. Acta Botanica Boreali-Occidentalia Sinica, 36, 1654-1661. [刘明航, 叶娟, 文涁 (2016). 热带雨林林内 小生境对木奶果和染木种子萌发与幼苗存活的影响. 西北植物学报, 36, 1654-1661.]

Lu JM, Johnson DJ, Qiao XJ, Lu ZJ, Wang QG, Jiang MX (2015). Density dependence and habitat preference shape seedling survival in a subtropical forest in central China. Journal of Plant Ecology, 8, 568-577.

Lucas-Borja ME, Candel-Pérez D, García Morote FA, Onkelinx T, Tíscar PA, Balandier P (2016). Pinus nigra Arn. ssp. salzmannii seedling recruitment is affected by stand basal area, shrub cover and climate interactions. Annals of Forest Science, 73, 649-656.

Luo Y, He F, Yu S (2013). Recruitment limitation of dominant tree species with varying seed masses in a subtropical evergreen broad-leaved forest. Community Ecology, 14, 189-195.

Ma DX, Liu RL (2012). Comparative study on germination of Bretschneidara sinensis seeds treated with solution extracted from forest litter and other methods. Forest Research, 25, 632-637. [马冬雪, 刘仁林 (2012). 天然群落 枯枝落叶浸提液与其它处理对伯乐树种子发芽的比较 研究. 林业科学研究, 25, 632-637.]

Marques MCM, Burslem DFRP (2015). Multiple stage recruitment limitation and density dependence effects in two tropical forests. Plant Ecology, 216, 1243-1255.

Marteinsdóttir B (2014). Seed rain and seed bank reveal that seed limitation strongly influences plant community as- sembly in grasslands. PLOS ONE, 9, e103352. DOI: 10. 1371/journal.pone.0103352.

Martinez-Ramos M, Alvarez-Buylla ER (1995). Seed dispersal and patch dynamics in tropical rain forests: a demographic approach. Écoscience, 2, 223-229.

Mayer R, Erschbamer B (2011). Seedling recruitment and seed-microsite limitation in traditionally grazed plant communities of the alpine zone. Basic and Applied Ecology, 12, 10-20.

McEuen AB, Curran LM (2004). Seed dispersal and recruitment limitation across spatial scales in temperate forest fragments. Ecology, 85, 507-518.

Mendoza I, Gómez-Aparicio L, Zamora R, Matías L (2009). Recruitment limitation of forest communities in a degraded Mediterranean landscape. Journal of Vegetation Science, 20, 367-376.

Molofsky J, Lanza J, Crone EE (2000). Plant litter feedback and population dynamics in an annual plant, Cardamine pensylvanica. Oecologia, 124, 522-528.

Moreira X, Abdala-Roberts L, Zas R, Merlo E, Lombardero MJ, Sampedro L, Mooney KA (2016). Masting behaviour in a Mediterranean pine tree alters seed predator selection on reproductive output. Plant Biology, 18, 973-980.

Muller-Landau HC, Wright SJ, Calderón O, Hubbell SP, Foster RB (2002). Assessing recruitment limitation: concepts, methods and case-studies from a tropical forest//Levey DJ, Silva WR, Wallingford MG. Seed Dispersal and Frugivory: Ecology, Evolution and Conservation. CABI, Wallingford. 35-53.

Münzbergová Z, Herben T (2005). Seed, dispersal, microsite, habitat and recruitment limitation: identification of terms and concepts in studies of limitations. Oecologia, 145, 1-8.

Overbeck G, Kiehl K, Abs C (2003). Seedling recruitment of Succisella inflexa in fen meadows: importance of seed and microsite availability. Applied Vegetation Science, 6, 97-104.

Palow DT, Oberbauer SF (2009). Soil type affects seedling shade response at low light for two Inga species from Costa Rica. Plant and Soil, 319, 25-35.

Pausas JG, Lamont BB, Paula S, Appezzato-Da-glória B, Fidelis A (2018). Unearthing belowground bud banks in fire-prone ecosystems. New Phytologist, 217, 1435-1448.

Putwain PD, Machin D, Harper JL (1968). Studies in the dynamics of plant populations: II. components and regulation of a natural population of Rumex acetosella L. Journal of Ecology, 56, 421.

Qian JQ, Wang ZW, Klimešová J, Lü X, Kuang WN, Liu ZM, Han XG (2017). Differences in below-ground bud bank density and composition along a climatic gradient in the temperate steppe of Northern China. Annals of Botany, 120, 755-764.

Rand TA, West NM, Russell FL, Louda SM (2020).

www.plant-ecology.com 
Post-dispersal factors influence recruitment patterns but do not override the importance of seed limitation in populations of a native thistle. Oecologia, 193, 143-153.

Record S, Kobe RK, Vriesendorp CF, Finley AO (2016). Seedling survival responses to conspecific density, soil nutrients, and irradiance vary with age in a tropical forest. Ecology, 97, 2406-2415.

Rey PJ, Ramírez JM, Sánchez-Lafuente AM (2006). Seed- vs. microsite-limited recruitment in a myrmecochorous herb. Plant Ecology, 184, 213-222.

Rosin C, Poulsen JR (2018). Seed traits, not density or distance from parent, determine seed predation and establishment in an Afrotropical forest. Biotropica, 50, 881-888.

Rother DC, Pizo MA, Siqueira T, Rodrigues RR, Jordano P (2015). Community-wide spatial and temporal discordances of seed-seedling shadows in a tropical rainforest. PLOS ONE, 10, e0123346. DOI: 10.1371/journal.pone. 0123346.

Russell ML, Vermeire LT (2015). Fire and nitrogen alter axillary bud number and activity in purple threeawn. Rangeland Ecology \& Management, 68, 65-70.

Sagar GR, Harper JL (1960). Factors affecting the germination and early establishment of plantains (Plantago lanceolata, P. media and P. major)//Harper JL. The Biology of Weeds. Blackwell, Oxford. 236-245.

Salazar A, Goldstein G, Franco AC, Miralles-Wilhelm F (2011). Timing of seed dispersal and dormancy, rather than persistent soil seed-banks, control seedling recruitment of woody plants in Neotropical savannas. Seed Science Research, 21, 103-116.

Schupp EW, Milleron T, Russo SE (2002). Dissemination limitation and the origin and maintenance of species-rich tropical forests//Levey DJ, Silva WR, Wallingford MG. Seed Dispersal and Frugivory: Ecology, Evolution and Conservation. CABI, Wallingford. 19-33.

Seabloom EW (2011). Spatial and temporal variability in propagule limitation of California native grasses. Oikos, 120, 291-301.

Siemann E, Rogers WE (2006). Recruitment limitation, seedling performance and persistence of exotic tree monocultures. Biological Invasions, 8, 979-991.

Slodowicz D, Humbert JY, Arlettaz R (2019). The relative effectiveness of seed addition methods for restoring or re-creating species rich grasslands: a systematic review protocol. Environmental Evidence, 8, 28. DOI: 10.1186/ s13750-019-0174-2.

Solbreck C, Knape J (2017). Seed production and predation in a changing climate, new roles for resource and seed predator feedback? Ecology, 98, 2301-2311.

Titus JH, Bishop JG (2014). Propagule limitation and competition with nitrogen fixers limit conifer colonization during primary succession. Journal of Vegetation Science, 25,
990-1003

Turnbull LA, Crawley MJ, Rees M (2000). Are plant populations seed-limited? A review of seed sowing experiments. Oikos, 88, 225-238.

Turnbull LA, Rees M, Crawley MJ (1999). Seed mass and the competition/colonization trade-off: a sowing experiment. Journal of Ecology, 87, 899-912.

Uriarte M, Bruna EM, Rubim P, Anciães M, Jonckheere I (2010). Effects of forest fragmentation on the seedling recruitment of a tropical herb: assessing seed vs. safe-site limitation. Ecology, 91, 1317-1328.

Urretavizcaya MF, Defossé GE (2013). Effects of nurse shrubs and tree shelters on the survival and growth of two Austrocedrus chilensis seedling types in a forest restoration trial in semiarid Patagonia, Argentina. Annals of Forest Science, 70, 21-30.

Vaughton G, Ramsey M (2001). Relationships between seed mass, seed nutrients, and seedling growth in Banksia cunninghamii (Proteaceae). International Journal of Plant Sciences, 162, 599-606.

Vilà M, Bartomeus I, Gimeno I, Traveset A, Moragues E (2006). Demography of the invasive geophyte Oxalis pes-caprae across a Mediterranean island. Annals of Botany, 97, 1055-1062.

Wang DL, Du J, Zhang BT, Ba L, Hodgkinson KC (2017). Grazing intensity and phenotypic plasticity in the clonal grass Leymus chinensis. Rangeland Ecology \& Management, 70, 740-747.

Wang Z, Zhang GS, Wang LH, Hao YL, Wen GS (2005). Seed yield, seed bank and regeneration of natural Sabina vulgaris community in mu us sandland. Journal of Arid Land Resources and Environment, 19, 195-200. [王哲, 张国盛, 王林和, 郝云龙, 温国胜 (2005). 毛乌素沙地天然臭柏 群落种子产量、种子库及幼苗更新. 干旱区资源与环境, 19, 195-200.]

Xiao ZS, Mi XC, Holyoak M, Xie WH, Cao K, Yang XF, Huang XQ, Krebs CJ (2017). Seed-predator satiation and Janzen-Connell effects vary with spatial scales for seed-feeding insects. Annals of Botany, 119, 109-116.

Xie TP, Zhang GF, Zhao ZG, Du GZ, He GY (2014). Intraspecific competition and light effect on reproduction of Ligularia virgaurea, an invasive native alpine grassland clonal herb. Ecology and Evolution, 4, 817-825.

Xu Y, Shen ZH, Li DX, Guo QF (2015). Pre-dispersal seed predation in a species-rich forest community: patterns and the interplay with determinants. PLOS ONE, 10, e0143040. DOI: 10.1371/journal.pone.0143040.

Yang YF, Bai YP, Li JD (2012). Spatial difference and regularity of seed dispersal of Ulmus macrocarpa in Horqin Sandy Land, China. Chinese Journal of Plant Ecology, 36, 747-753. [杨允菲, 白云鹏, 李建东 (2012). 科尔沈沙地黄榆种子散布的空间差异及规律. 植物生 
态学报, 36, 747-753.]

Yang YF, Li JD (1996). Vegetative propagation of some rhizomatous grasses on Song-nen Plain and their population stability. Acta Prataculturae Sinica, 5, 43-48. [杨允菲, 李 建东 (1996). 松嫩平原几种根茎型禾草种群的营养繁 殖特性及其持续更新分析. 草业学报, 5, 43-48.]

Yang YF, Wei CY, Zhang BT, Liu B (2005). Dynamics of bud flow and bud bank of Phragmites communis population in dry land habitat of alkalinized meadow in the Songnen Plains of China. Chinese Journal of Applied Ecology, 16, 854-858. [杨允菲, 魏春雁, 张宝田, 刘宝 (2005). 松嫩 平原碱化草甸旱地生境芦苇种群的芽流和芽库动态. 应用生态学报, 16, 854-858.]

Zárate DA, Andresen E, Santos-Heredia C (2019). Seed fate and seedling recruitment in monkey latrines in rustic cocoa plantations and rain forest in southern Mexico. Journal of Tropical Ecology, 35, 18-25.

Zhang HX, Zhou DW (2016). Current status in seed ecology. Pratacultural Science, 33, 2221-2236. [张红香, 周道玮 (2016). 种子生态学研究现状. 草业科学, 33, 2221-2236.]

Zhang JF, Li QH, Wang LL, Gao MY, Sun GJ, Xing L (2018). Effects of different nitrogen addition on bud bank traits and branching architecture of Nitraria tangutorum seedlings. Forest Research, 31, 158-166. [张俊菲, 李清河, 王 林龙, 高明远, 孙高洁, 邢否 (2018). 白刺幼苗芽库及 枝系构型对不同氮添加水平的响应. 林业科学研究, 31, 158-166.]

Zhang YB, Li JW, Zhang H, Li JQ, Wu P, Zhao J (2005). Analysis on the factors cause the failure of Populus euhpratica sextual regeneration in nature. Science Techno- logy and Engineering, 5, 467-472. [张玉波, 李景文, 张 昊, 李俊清, 乌平, 赵健 (2005). 额济纳胡杨有性繁殖 失败因素分析. 科学技术与工程, 5, 467-472.]

Zhao GJ, Xu XL, Ma HC, Huang D, Yang JJ, Shu YY, Ge L, Ping $P$ (2016). Causes of difficulties with natural regeneration of a Bombax ceiba population in Hong-He dry-hot valleys (DHV). Acta Ecologica Sinica, 36, 1342-1351. [赵 高卷, 徐兴良, 马焕成, 黄冬, 杨建军, 舒媛媛, 葛娈, 平盼 (2016). 红河干热河谷木棉种群的天然更新. 生态 学报, 36, 1342-1351.]

Zhao LP, Tan ST, Bai X (2016). Effect of grazing and grazing exclusion management on offspring recruitment in a semiarid steppe on the Loess Plateau. Journal of Northwest A\&F University (Natural Science Edition), 44(9), 27-34. [赵凌平, 谭世图, 白欣 (2016). 封育和放牧对黄土高 原典型草原繁殖更新的影响. 西北农林科技大学学报 (自然科学版), 44(9), 27-34.]

Zhou Y, Chen X, Wei XL, Wu Q, Li CC (2015). Effects of litter on the seedling regeneration and seed germination of Rhododendron agastum. Scientia Silvae Sinicae, 51(3), 65-74. [周艳, 陈训, 韦小丽, 伍庆, 李朝婵 (2015). 调 落物对迷人杜鹃幼苗更新和种子萌发的影响. 林业科 学, 51(3), 65-74.]

Zimmermann J, Higgins SI, Grimm V, Hoffmann J, Münkemüller T, Linstädter A (2008). Recruitment filters in a perennial grassland: the interactive roles of fire, competitors, moisture and seed availability. Journal of Ecology, 96, 1033-1044.

责任编委: 邓建明 责任编辑: 李 敏 